\title{
Solubilization of Phosphorus Containing Mineral by Bacteria from Rhizospheric Region of Walnut (Juglans regia)
}

\author{
Zaffar Bashir ${ }^{1 *}$, M.Y. Zargar ${ }^{1}$, Tariq A. Bhat ${ }^{2}$, Shaheen Kousar ${ }^{3}$, \\ Z.A. Baba ${ }^{1}$ and F.A. Mohiddin ${ }^{3}$
}

${ }^{1}$ Division of Basic Sciences and Humanities, ${ }^{2}$ Division of vegetable sciences, ${ }^{3}$ Division of Plant pathology, Sher-e-Kashmir University of Agricultural Sciences and Technology, Shalimar, Srinagar, Kashmir 190025, India

*Corresponding author

\section{A B S T R A C T}

\section{Keywords}

Phosphorus Solubilizing Bacteria (PSB), Walnut (Juglans regia),

Rhizosphere and isolates

Article Info

Accepted:

12 July 2018

Available Online:

10 August 2018
Microbial biodiversity in the soil plays a significant role in metabolism of complex molecules and help in plant nutrition. Phosphate solubilizing Bacteria (PSB) increases availability of phosphorus, therefore reducing the application of chemical fertilizers. The present study was aimed to isolate and characterize the selected phosphorus solubilizing bacteria from Rhizospheric regions of Walnut (Juglans regia). Walnut rhizospheric region samples were collected from the different sites of Kashmir, India. Each sample was enriched in Pikovskayas's solid medium ( $\mathrm{pH} 7.5$ at $30^{\circ} \mathrm{C}$ for 5 days). Out of 25 isolates, 7 isolates showed highest zone of clearance on Pikovskayas's medium and were morphologically and biochemically characterized. These 7 isolates belong to genus Bacillus (PSB8, PSB9, PSB13, 14), Pseudomonas (PSB10, PSB11) and Micrococcus (PSB12).

\section{Introduction}

Numerous soil microflora were reported to solubilize insoluble phosphorus complexes in to solution and make it possible for its use by the plant (Tripura et al., 2005). Phosphorus is the major essential macronutrients for plants growth and development. It plays pivotal in photosynthesis, respiration, energy storage and transfer, cell division, cell enlargement and some other processes in the plants. It is applied to the soil in the form of chemical fertilizers. Its availability to the plant utilization is limited. As inorganic phosphate, it is immobilized rapidly and becomes unavailable to plants (Akhtar et al., 2010). Among the alternative $\mathrm{P}$ sources, the most important is locally available rock phosphate (Khan et al., 2009). Majority of the soils throughout the world are $\mathrm{P}$ deficient (Muhammad, 2012). The concentration of Bioavailable $\mathrm{P}$ in soil is very low getting to the level of $1.0 \mathrm{mg} \mathrm{kg}-1$ (Goldstein, 1994). Plants absorb P as phosphate anions (HPO4-) 
or $\mathrm{H}_{2} \mathrm{PO}^{4-}$ ) from soil (Rodriguez and Fraga, 1999).

Phosphate anions are highly reactive in the soil and their precipitation is soil $\mathrm{pH}$ dependent. In acidic soils phosphate anions get precipitated with free oxides and hydroxides of iron and aluminium, but in alkaline soils calcium is the main element involved in P fixation (I gual et al., 2001). Indian soils are characterized by poor and medium status with respect to available $\mathrm{P}$ (Baby, 2002, Li et al., 2003, Ramanathan et al., 2004).

Phosphorus solubilizing microorganisms (PSM) play a vital role in soil $\mathrm{P}$ dynamics and availability of phosphate to plants (Richardson, 2001). There are various types of soil microbes which can solubilize this fixed form of $\mathrm{P}$ and make available to plants (Illmer et al., 1995; Kucey et al., 1989; Richardson, 2001; White law et al., 1999). Many soil microorganisms particularly those present in rhizosphere of plants, are able to solubilize fixed form of $\mathrm{P}$ to soluble form and makes it available to plants (Dave and Patel, 2003; Dubey et al., 1997; Narayanasamy et al., 1981). The principal mechanism of $p$ solubilization is the production of organic acids and phosphatase enzymes which play key role in phosphatase solubilization in the soil (Surange et al., 1995; Duttan and Evans, 1996; Nahas, 1996; Shankar et al., 2013).

\section{Objectives}

Isolation of PSB from rhizospheric soils.

Characterization of PSB strains from rhizospheric soils of walnut.

\section{Materials and Methods}

It was a laboratory scale study and whole of the work was undertaken in the laboratories of
Division of Plant Pathology SKUASTKashmir. Different strains of phosphate solubilizing bacteria (PSB) were isolated from walnut rhizospheric soils

\section{Sample preparation}

In order to isolate PSB, 10 mixed soil samples were collected from walnut rhizospheric soils, from various sites of Kashmir, India. The samples were collected at a depth of 10-30 $\mathrm{cm}$. All the tools used for soil sampling were surface sterilized using $70 \%$ ethanol and soil samples were placed in sterile bags, transported to laboratory, stored at $4{ }^{0} \mathrm{C}$ and processed within a week.

\section{Isolation and screening of efficient PSB strains}

The isolation of phosphorus solubilizing bacteria (PSB) from rhizospheric soils of walnut was done by following the serial dilution technique. For isolation, soil samples were serially diluted from $10^{-3}$ to $10^{-6}$ and inoculated on modified Pikovskayas's agar medium which consists of : glucose $10 \mathrm{~g}$, Magnesium sulphate $0.1 \mathrm{~g}$, ferrous sulphate trace, Manganese sulphate trace, Tricalcium phosphate as $\mathrm{P}$ source, agar $15 \mathrm{~g}$, distilled water $1 \mathrm{~L}, \mathrm{pH}$ was adjusted to 7 before sterilization, followed by pour plate technique and the $48 \mathrm{~h}$ incubation at $30^{\circ} \mathrm{C}$, discrete colonies showing halo zones were picked up, sub cultured in Nutrient agar slants and then preserved (Pikovskayas's, 1948).

\section{Characterization of PSB Strains}

\section{Morphological characters}

Suspension of each purified culture was prepared and poured on plates having solid media by spread plate method. The inoculate plates were incubated at $25^{\circ} \mathrm{C}$ till the appearance of colonies. Morphological 
characters of colonies like size, shape, color and elevation were measured as (Goenadi et al., 2000).

\section{Microscope characters}

The isolated strains were heat fixed called as smear. Crystal violet was flooded for one minute and washed gently by tape water. Then the smears were exposed to Gram's iodine for one minute and washed and drained carefully. 95\% alcohol was applied for 30 seconds and washed. Finally the smears were washed and drained with $0.25 \%$ safranine for 30 seconds and examined under microscope. It focused on shape and size of bacteria. Pink colored bacteria were named as Gram negative while purple colored were named as Gram positive

\section{Estimation of phosphate solubilization efficiency}

For testing the Psolubilizing capability of PSB strains, each PSB culture was poured on Pikovskayas's agar plate containing insoluble tricalcium phosphate. The plates having culture were incubated for 4 days at $28^{\circ} \mathrm{C}$.Solubilization index was measured by Edi-Premono formula (Edi- Premono et al., 1996).

\section{PSI $=\frac{\text { Colony Diameter }+ \text { Halo Zone Diameter }}{\text { Colony Diameter }}$}

\section{Biochemical tests}

The most efficient PSB strains were characterized by biochemical tests (Smibert and Krieg, 1994).

\section{Identification of bacterial strain}

Different tests like Biochemical, Morphological and Physiological of the selected phosphate solubilizing bacterial isolates were performed for identification, as per methods defined in Bergey's Manual of Determinative Bacteriology (J.G. Holt, et al., 1994). The isolates belong to genus Bacillus, Pseudomonas, Micrococcus. PSB 8, 9, 13, 14 belong to Bacillus, PSB 10, 11 to Pseudomonas, and PSB12 to Micrococcus.

\section{Statistical analysis}

Statistical comparison of different PSB strains for $\mathrm{P}$ solubilization efficiency, PSI was undertaken.

\section{Results and Discussion}

Isolation, purification and characterization of PSB

Phosphorus is an important limiting factor in agriculture production and microbial activation seems to be an effective way to solve the solidified phosphorus in the soil.

Microorganisms capable of producing a zone of clearance due to the solubilization of inorganic phosphorus (Das, 1989) and were routinely screened in the laboratory by a plate assay method using Pikovskayas's agar medium (pikoviskayas 1948) or tricalcium phosphate medium (Nautiyal, 1999).

The primary screening protocol used for the identification of PSB strains usually depends on the use of tricalcium phosphate as a sole source of $\mathrm{P}$ in indicator plates. We decided to use tricalcium phosphate as source of $\mathrm{P}$ for screening of PSB isolated from rhizospheric soils of Walnut.

Results indicates that significant clear halo zone formation around bacterial colonies on Pikovskayas's agar with tricalcium phosphate as $\mathrm{P}$ source, which was in agreement with reports of (Chung et al., 2005, Barroso and Mahas, 2005) (Fig. 1and 2). 
Table.1 Morphological characters of phosphorus solubilizing and mineralizing bacteria

\begin{tabular}{|l|l|l|l|l|l|l|l|l|l|l|}
$\begin{array}{l}\text { Isolates } \\
\text { PSB }\end{array}$ & Pigmentation & Margin & \multicolumn{2}{|l|}{$\begin{array}{l}\text { Gram } \\
\text { reaction }\end{array}$} & $\begin{array}{l}\text { Slightly } \\
\text { PSised }\end{array}$ & $\begin{array}{l}\text { Highly Trans- } \\
\text { raised }\end{array}$ parent & Opaque Shape & Spore \\
\hline PSB8 & White & Entire & + & - & + & + & - & Long rods & + \\
\hline PSB9 & Whitish & Entire & + & + & - & - & + & Short rods & + \\
\hline PSB10 & Creamy & Entire & - & + & - & - & + & Short rods & - \\
\hline PSB11 & creamy & Entire & - & + & - & - & + & Short rods & - \\
\hline PSB12 & Creamy & Elevated & + & - & + & - & + & Minute & - \\
\hline PSB13 & White & Entire & + & - & + & + & - & Short rods & + \\
\hline PSB14 & White & Entire & + & - & + & + & - & Short rods & + \\
\hline
\end{tabular}

Table. 2 biochemical characterization of 7 psb isolates

\begin{tabular}{|l|l|l|l|l|l|l|l|l|l|l|l|l|l|l|l|l|l|c|}
\hline $\begin{array}{c}\text { Isolate } \\
\text { S PSB }\end{array}$ & C & U & O & Dn & M.R & VP & ST & Ca & A.P & G.P & $\mathbf{H}_{2}$ S & Gel & NaCl & Su & M & G & Cit & $\mathbf{k}$ \\
sol.
\end{tabular}

$\mathrm{C}=$ Catalase test, $\mathrm{U}=$ Urea Hydrolysis, $\mathrm{O}=$ oxidase, $\mathrm{Dn}=$ Denitrification test, $\mathrm{MR}=$ Methyl red test, V.P $=\mathrm{V} . \mathrm{P}$ test,

$\mathrm{ST}=$ Starch Hydrolysis test, $\mathrm{Ca}=$ Casein test, $\mathrm{A} . \mathrm{P}=$ Acid production, $\mathrm{G} . \mathrm{P}=$ Gas production, $\mathrm{H} 2 \mathrm{~S}=\mathrm{H}_{2} \mathrm{~S}$ production test, $\mathrm{Gel}=$ Gelatine hydrolysis, $\mathrm{Cit}=$ citrate test, $\mathrm{SU}=$ sucrose, $\mathrm{M}=$ Mannital, $\mathrm{G}=$ glucose, $\mathrm{NaCl}=70 \% \mathrm{NaCl}, \mathrm{K}$ Sol $=$ Potassium solubilization,$+=$ positive,$-=$ negative .

Table.3 Zone of clearance and phosphorus solubilization index of ten isolates

\begin{tabular}{|l|c|c|c|}
\hline $\begin{array}{l}\text { PSB } \\
\text { isolates }\end{array}$ & $\begin{array}{c}\text { Diameter of zone of } \\
\text { Clearance }(\mathrm{cm})\end{array}$ & $\begin{array}{c}\text { Colony Diameter } \\
(\mathrm{cm})\end{array}$ & $\begin{array}{c}\text { Phosphorus solubilization } \\
\text { index (PSI) }\end{array}$ \\
\hline PSB8 & 0.60 & 0.50 & 2.20 \\
\hline PSB9 & 0.40 & 0.30 & 2.33 \\
\hline PSB10 & 0.70 & 0.40 & 2.75 \\
\hline PSB11 & 0.50 & 0.30 & 2.67 \\
\hline PSB12 & 0.60 & 0.40 & 2.50 \\
\hline PSB13 & 0.60 & 0.30 & 3.00 \\
\hline PSB14 & 0.70 & 0.40 & 2.75 \\
\hline
\end{tabular}


Fig.1 P Solubilization on PVK medium

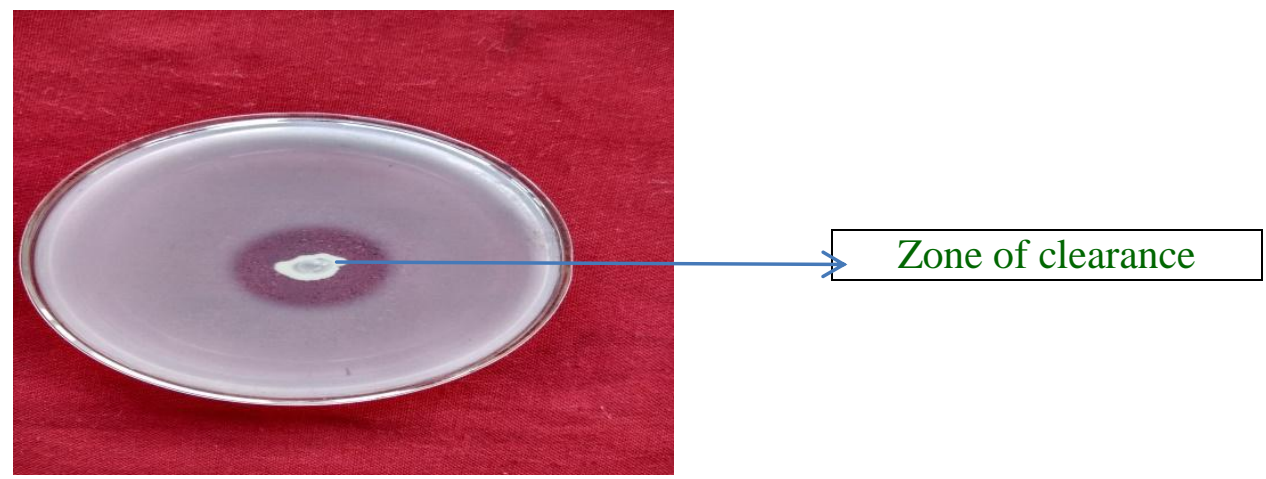

Fig.1a Graphical representation of solubilization index

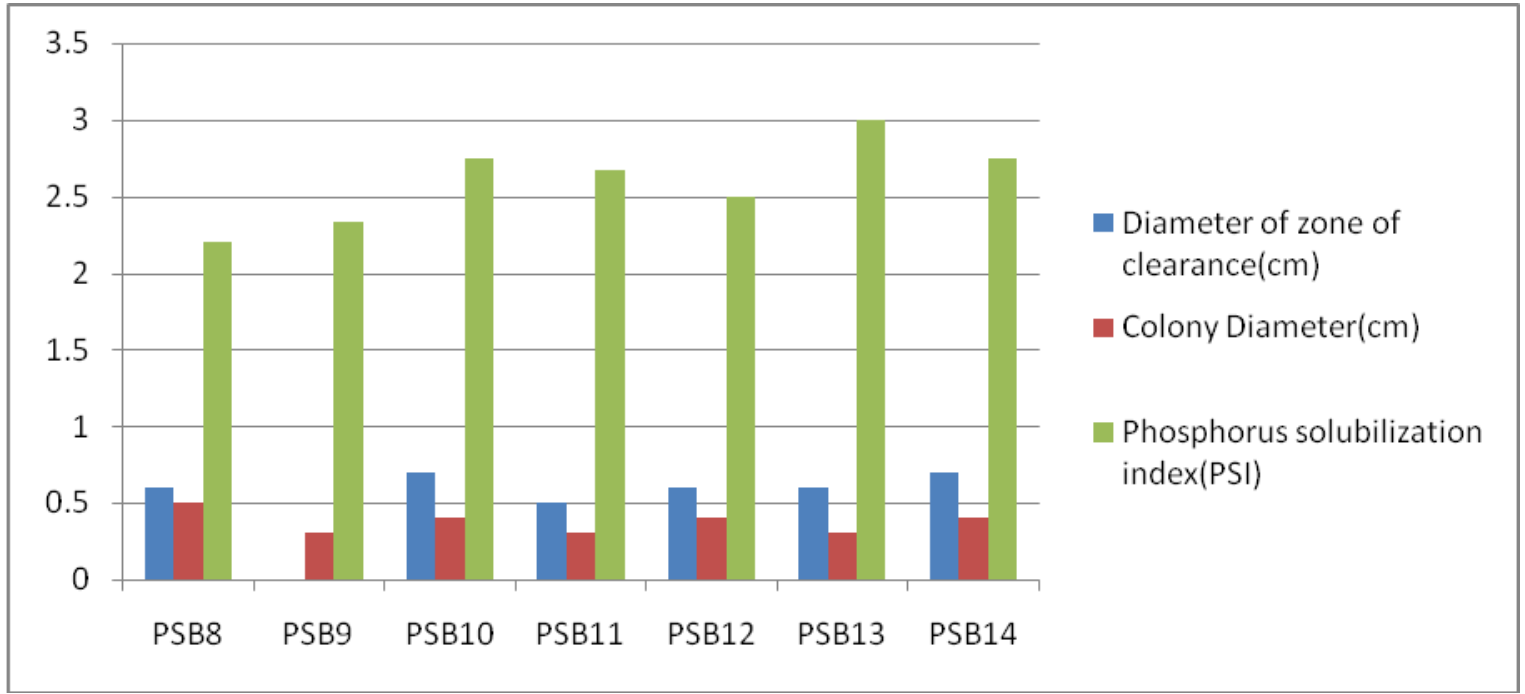

The isolates were also tested for $\mathrm{K}$ solubilization on specific medium. According to morphological and biochemical characterization the microorganisms showing zone of clearance belongs to the bacterial genera, and various biochemical tests were performed (Table 1 to 3 ). From the various PSB isolates, 7 best strains were selected on the basis of solubilization index for further Characterization. The characterization of PSB was done by the following tests.

\section{Gram test}

Gram test was performed to check whether PSB strains were gram positive or negative.
In this test few strains retained pink color and were categorized as gram negative and few retained purple and are gram positive.

\section{P-solubilization test}

For the solubilization test, PSB strain were cultured on Pikovskayas's agar medium and placed in incubator at $28^{\circ} \mathrm{C}$ for 4 days.

The formation of halo zone around the bacterial colony confirmed them as $\mathrm{P}$ solubilizer (Seshadari et al., 2000).

All the 7 strains are best $\mathrm{P}$ solubilizers (Table 3) 


\section{Effect of PSB on pH of the medium}

All the selected 7 PSB strains, showed maximum changes in $\mathrm{pH}$. Change in $\mathrm{pH}$ by PSB isolates in broth medium was determined by using pH meter. Maliha et al., (2004) and Chen et al., (2005) reported that PSB strains secrete various organic acids which drop the $\mathrm{pH}$ of the mediums resulting in $\mathrm{P}$ solubilization. The drops of $\mathrm{pH}$ in PSB broth culture has been reported by several researchers like Rashid et al., (2004) and Panhwar et al., (2009), who found PSB very effective in lowering the $\mathrm{pH}$ of the broth medium. Present study results are in line with their findings as they said about PSB's inoculation result in change of $\mathrm{pH}$. The morphological, biochemical and solubilization index is given in tables 1 to 3 .

Walnut rhizospheric soil presented a diverse population of PSBs. All the screened isolates PSB8 to PSB14 were more efficient in $\mathrm{P}$ solubilization. Therefore these isolates can be used in the production of biofertilizers in order to improve growth of agricultural crops in $\mathrm{P}$ deficient soils, constituting an alternative to the application of $\mathrm{P}$ fertilizers.

\section{Acknowledgement}

Authors are thankful to Division of Plant pathology Sher-e-Kashmir University of Agricultural Sciences and TechnologyShalimar, Srinagar, Kashmir 190025, India for their keen interest, Scholastic guidance, supervision and encouragement to accomplish this research.

\section{References}

Akhtar N, Iqbal A, Qureshi MA, Khan KH. 2010. Effect of phosphate solubilizing bacteria on the phosphorus availability and yield of cotton (Gossypium hirsutum). Journal of Scientific Research 40(1), 15-24.

Baby, U. I.2002. Biofertilizers in tea. Planters' Chronicle 98: 395-396.

Barroso, C.B., Nahas, E., 2005. The status of soil Phosphate fractions and the ability of fungi to dissolve hardly Soluble Phosphates. Appl. Soil Ecol. 29, 73-83.

Chen, Z., Ma, S., and Lio, L. (2008) Studies on phosphorus solubilizing activities of a strain of phosphobacteria isolated from chestnut type soil in China. Bioresource Technology 99: 6702-6707.

Chung, H., Park, M., Madhaiyan, M., Seshadri, S., Song, J., Cho, H., Sa, T., 2005. Isolation and Characterization of Phosphate Solubilizing bacteria from the rhizosphere of crop plants of Korea. Soil Biol. Biochem. 37, 1970-1974.

Das AC (1989). Utilization of insoluble Phosphates by soil fungi. J Indian Soc Soil Sci 58:1208-1211

Dave, A. and H. H. Patel. 2003. Impact of different carbon and nitrogen sources on phosphate solubilization by Pseudomonas fluorescens. Indian Journal of Microbiology 43: 33-36.

Dubey, S. K., V. R. Balasundaram, L. M. Pant, N. Jayasheela, B. R. Kawale and B. Mishra. 1997. Effect of phosphate dissolving bacteria applied with rock phosphate on nodulation and yield of rain fed soybean under different agriculture climatic conditions. Journal of Indian Society for Soil Science 45: 503-505.

Dutton, V.M., and Evans, C.S. 1996. Oxalate production by fungi: its role in pathogenicity and ecology in the soil environment. Can. J. Microbiol., 42: 881-895.

Edi-Premono M, Moawad A, Vleck PLG. 1996. Effect of phosphate solubilizing Pseudomonas putida on the growth of maize and its survival in the 
rhizosphere. Indonesian. Journal of Crop Science 11, 13-23.

Goenadi DH, Siswanto, Sugiarto Y. 2000. Bio activation of poorly soluble phosphate rock with Phosphorus solubilizing fungus. Soil Science Society of America Journal 64, 927-932.

Goldstein AH.1994. Involvement of the quinoprotein glucose dehydrogenises in the Solubilization of exogenous phosphates by gram negative bacteria. In: A. Torriani.

Igual, J.M., Valverde, A., Cervantes, E., and Velázquez, E. (2001). Phosphate solubilizing bacteria as inoculants for agriculture: use of updated molecular techniques in their study.Agronomie21: 561-568.

Illmer, P., A. Barbato and F. Schinner. 1995. Solubilization of hardly-soluble AlPO4 with $\mathrm{P}-$ solubilizing microorganisms. Soil Biology and Biochemistry.27: 265270.

J.G. Holt, Krieg, N.R. Sneath, P.H.A. Staley J.T. Williams S.T. (1994) In, Bergy's Manual of Determinative Bacteriology, (9th Ed.), Williams and Wilkins Pub, MD, USA.

Khan, A. A., Jilani, G., Akhtar, M.S., Naqvi, S.S., Rasheed, M., 2009. Phosphorus solubilizing bacteria: occurrence, mechanisms and their role in crop production. J. Agric. Biol. Sci. 1, 4858 .

Kucey, R. M. N., H. H. Jenzen and M. Leggett. 1989. Microbial mediated increases in plant available phosphorus. Advances in Agronomy 42: 199-228.

Li, S. T., J. I. Zhou, H. Y. Uang, X. Q. Chen and C. W. Du. 2003.Characteristics of fixation and release of phosphorus in three soils. Acta Pedologzca Sznica 40: 908-914.

Maliha RK, Samina, Najma A, Sadia A, Farooq L. 2004.Organic acids production and phosphate Solubilization by phosphate solubilizing microorganisms under in vitro conditions. Pakistan Journal of Biological Sciences 7, 187-196.

Muhammadi K. 2012. Phosphorus solubilizing Bacteria, occurrence, mechanisms and their role in crop production. Journal of Research and Environment 2(1), 80-85.

Nahas, E. 1996. Factors determining rock phosphate solubilization by microorganism isolated from soil. World J. Microb. Biotechnol., 12: 1823.

Narayanasamy, G., S. K. Ghosh and M. C. Sarkar. 1981. Chemical and mineralogical composition of P-rock deposits occurring in India. Fertilizer News 26: 3-9.

Nautiyal CS (1999).An efficient microbiological growth medium for screening phosphate solubilizing microorganisms. FEMS Microbiol Lett 182:265-270

Panhwar QA, Radziah O, Sariah M, Razi IM. 2009. Solubilization of phosphate forms by phosphate solubilizing bacteria isolated from aerobic Rice. International Journal of Agriculture Biology 11, 667673.

Pikovskaya RI (1948). Mobilization of Phosphorus in soil in connection with vital activity of some microbial species. Microbiologiya 17:362-370

Raghothama, K.G. (1999). Phosphate acquisition. Annual Review of Plant Physiology and Plant Molecular Biology 50: 665-6693.

Ramanathan, S., K. Natarajan and P. Stalin. 2004. Effect of foliar nutrition on grain yield of rice fallow black gram. Madras Agriculture 91: 160-163.

Rashid M, Khalil S, Ayub N, Alam S, Latif F (2004) Organic acids production and phosphate solubilization by phosphate solubilizing microorganisms (PSM) 
under in vitro conditions. Pak J Biol Sci 7: $187-196$

Richardson, A. E., 2001.Prospects for using soil microorganisms to improve the acquisition of phosphorus by plants. Funct. Plant Biol. 28, 897-906.

Rodríguez, H., and Fraga, R. (1999). Phosphate solubilizing bacteria and their role in plant growth promotion. Biotechnology Advances 17: 319-339.

Sashidhar, B., and Podile, A.R. (2010). Mineral phosphate solubilization by rhizosphere bacteria and scope for manipulation of the direct oxidation pathway involving glucose dehydrogenase. Journal of Applied Microbiology 109: 1-12.

Seshadri S, Muthukum arasamy R, Lakshminarasimhan C, Ignacimuthu S. 2000. Solubilization of inorganic phosphates by Azospirillum halopraeferans. Current Science79, 565- 567.
Shankar, T., Sivakumar, T., Asha, G. Sankaralingam S. and Meenakshi Sundaram V. 2013. Effect of PSB on Growth and Development of Chilli and Maize Plants. World Appl. Sci. J., 26(5): 610-617.

Smibert RM, Kreig NR. 1994. Phenotypic characterization. In: methods for general and molecular bacteriology. Washington DC: American Society of Microbiology, No. 12.p. 607-654.-49.

Surange, S., Wollum, A. G., Kumar, N. and Nautiyal, C. S. 1995. Characterization of Rhizobium from root nodules of leguminous trees growing in alkaline soils. Can. J. Microbiol., 43: 891-894.

Whitelaw, M. A., T. J. Harden and K.R. Helyar.1999. Phosphate solubilisation in solution culture by the soil fungus Penicillium radicum. Soil Biology and Biochemistry 31: 655-656.

\section{How to cite this article:}

Zaffar Bashir, M.Y. Zargar, Tariq A. Bhat, Shaheen Kousar, Z.A. Baba and Mohiddin, F.A. 2018. Solubilization of Phosphorus Containing Mineral by Bacteria from Rhizospheric Region of Walnut (Juglans regia). Int.J.Curr.Microbiol.App.Sci. 7(08): 2391-2398. doi: https://doi.org/10.20546/ijcmas.2018.708.241 